\title{
140 years on
}

\section{Nature 創刊 140 年を迎えて}

Nature Vol. 462(12)/5 November 2009

創刊記念日にあたり、過去を振り返り現在を認識するとともに、それを足場として、未来に目を向けていきたい。

Nature の創刊号は 1869 年 11 月 4 日に発行された。2009 年 11 月 5 日号は 7269 号に当たる。Nature は、幾度かの 戦争を生き抜いてきた（その間に発行中止になったことが 少なくとも一度はあった)。今のところ、伝統的な出版モ デルに対するインターネットの猛攻撃にも耐えていること を考えれば、少しは満足感に浸つても許されるかもしれな い。Nature に揭載される論文は被引用回数が多いが、それ には十分な理由があると思われる。Natureを読みたい人々 は大勢いて、電子版の読者数は毎月数百万人に及ぶ。この ような状況の中で、我々は、どこをどう自己批判すべきな のだろうか。もちろん読者は、多くの指摘を用意している と思うが、我々の側から、そのいくつかを示してみたい。 その 1 つは、Natureが人々にどのように利用され、悪 用されているのかを監視し、場合によっては、それに対抗 する必要があるという点だ。

Nature の歴史、とりわけ過去数十年間の歴史におい て、ジャーナルとしての Nature の目標は、自然科学およ びそれを越えた分野に対して、多大な影響を広範囲に与 える論文を出版することだった。この目標を達成するた め、強固な独立精神をもつて、多くの努力がなされてきた。 Natureの編集者は、学会や編集委員会との結びつきがな く、何らの商業的要請とも無関係であるため、記事や論文 の掲載に関する最終決定は、常に我々独自に進めてきた。 投稿論文について 3 人の査読者全員が否定的な評価を下 した場合でも、この 3 人が考えるより興味深い論文だと 確信し、その評価を覆したこともあつた。こうした判断の 正当性は、コミュニティーの反応や被引用回数によって一 般に確認されてきたようにみえる。

しかし、我々の判断が、妥当な範囲を逸脱して重視され るケースもある。Natureに揭載された論文の影響で、多 額の補助金、慈善寄付金、特席教授の地位が与えられて いるが、この場合、独自になされるべき判断に代わって、 Natureの編集者の判断が事実上利用されている。これは、 意思決定者の責任放棄であり、避けるべき落とし穴である。

これに関連して、研究者が「トップクラスのジャーナル」
に論文を揭載しなければならないという重圧に直面してい る事実があり、これは我々にとつて苦しみの種だ。むしろ 我々は、未熟で粗雑なインパクトファクターを超えて、論 文の引用やその他の効果・影響に対して、より透明性を確 保すべきだと考える。また科学者の他の仕事のインパクト、 すなわち、データベースへの寄与や長くつらい査読作業 などをきちんと記録する、新しいシステムの創設を支持し たい。我々としては、表面に現れにくいこうした重要な功 績を把握できる独自のシステムを開発し、同じ目標をもつ 人々と一緒になって前進していきたいと考えている。

Nature は、学術ジャーナルとしての役割と同時に、補 完的にサイエンスマガジンとしての役割も担っている。本 誌は、近年、ジャーナリズムコンテンツを強化し、外部の 執筆者によるOpinion 記事の揭載を始めたが、今後の展 開に期待してほしいと思う。その一例がコラムニストの導 入だ。11月 5 日号では、2007 年 1 月以来、科学と政策 の交わるコラム記事を執筆し続けてきた David Goldston による「Party of One」の最終回を揭載した。このコラム はデビュー以来、米国の政策立案者の必読コラムとなり、 「The scientist delusion」と題された宗教に関する記事 (Nature 2008 年 1 月 3 日号 17 ページ) は、2009年の 米国サイエンスライター協会賞の名誉表彰作品となった。 Goldston のコラムの成功を踏まえて、Natureでは、月 1 回連載のコラムニスト 2 人が新たに誕生する。

最も本質的なこととして、Natureには、論文著者・記事 執筆者・読者の価值観が反映されていなければならない。科 学の中核をなす価值観である客観性、独立性、自己批判的思 考、そして観察、実験、探究へのひたむきな衝動も、良質の ジャーナリズムと編集にとって重要な原則だ。サイエンスマ ガジンと学術ジャーナルの風変わりな混合体である Nature は、これらの原則に従いつつ、科学に真剣に興味をもつ研究 者や多くの人々に対して、その人生や仕事に大きな価值を加 えていかなければならない。それなくして、読者の敬意は持 続しないと考えている。こうした大望の実現に向け、我々は、 今後もまた強固な姿勢を堅持していく。（菊川要 訳） 